\title{
Acknowledgements
}

I would like to thank Professor Chas Critcher and the Film, Media and Communications Research Centre at Sheffield Hallam University for financing the first period of study leave that enabled me to formulate the proposal for this book and to write two articles on Jean Baudrillard and The Matrix Trilogy. I would also like to thank the Arts and Humanities Research Council and Sheffield Hallam University for jointly financing the second, lengthier period of study leave, necessary to produce a book on the topic. My friends and former colleagues from Sheffield Hallam University were extremely good about shouldering the extra burden of work caused by my leave without complaining too much! I am particularly indebted to: Gerry Coubro, Sheldon Hall, Shelley O'Brien, Suzanne Boujada, Suzanne Speidel and Tom Ryall and would like to take this opportunity to thank them all for their support and to say how much I miss having them around.

During the course of writing on The Matrix Trilogy, I have had the opportunity of presenting papers in a wide variety of different venues, including three very stimulating conferences: Screen, Literature on Screen and Philosophy \& Film/Film \& Philosophy. The second was crucial to the development of the book in that Kamilla Elliott's helpful advice enabled me to begin to formulate a key line of argument. The third conference was tremendous fun (thank you Greg Tuck and Havi Carel), which is just as well as it resulted in my having to rethink my conclusion. It also brought about the opportunity to meet Tom Wartenberg whom I must thank for a most interesting email correspondence.

Any book is always a project that embroils friends and family. 


\section{x Acknowledgements}

As usual I cannot imagine writing this without the helpful encouragement of Rachel Jones who has now developed a summary of my position that is much clearer than my own! My understanding and appreciation of adaptation theory has been greatly enhanced by innumerable, stimulating conversations with Suzanne Speidel. I am also indebted to Richard Dyer for his wonderfully sustaining enthusiasm - indeed his support has been absolutely crucial to the development of the project into the final form. The clarity and precision of the final form is largely due to Jane Worrall's meticulous proof reading and bibliographic skills. Finally, I must thank my husband, David Wood, for shouldering more than his share of domestic duties and still being willing to proof read in the evenings and must take this opportunity of putting in print that he is, officially, a gem. 